Article

\title{
Comparison of tribological properties and structure of coatings produced in powder flame spraying process on grey cast iron
}

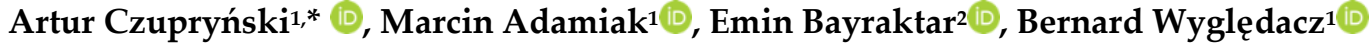 \\ 1 Silesian University of Technology, Poland \\ marcin.adamiak@polsl.pl (M.A.); bernard.wygledacz@polsl.pl (B.W.) \\ 2 School of Mechanical and Manufacturing Engineering, Supmeca/LISMMA - Paris, France \\ bayraktar@supmeca.fr (E.B.) \\ * Correspondence: artur.czuprynski@polsl.pl (A.C.)
}

Received: 15.02.2020 ; Accepted: 27.03.2020

\begin{abstract}
In this article results of tribological and structural properties comparison of flame sprayed, by SupJet-S-Eutalloy ${ }^{\circledR}$ multipurpose system, two self-fluxing alloys of Ni-B-Si type in the form of powder for spraying with remelting are presented. Layers were produced on EN-GJL-250 grade grey cast iron with flake graphite in an austenitic matrix. Abrasive wear resistance examination acc. to ASTM G65-00 and erosive wear resistance examination acc. to ASTM G76-2 were performed. Obtained results were compared with abrasion-resistant steel Hardox ${ }^{\circledR} 400$. Macro- and microscopic examination were carried enabling layer quality evaluation and structure of examined layer and base material determination. X-ray microanalysis was performed to obtain qualitative and quantitative data about microareas chemical composition. The Eutalloy ${ }^{\circledR}$ BronzoChrom 10185 powder flame sprayed layer with higher Boron and Silicon content was characterized by $13 \%$ lower wear intensity under mineral abrasive conditions and about 30\% higher erosion wear resistance than Eutalloy ${ }^{\circledR}$ NiTec 10224 powder flame sprayed layer.
\end{abstract}

Keywords: powder flame spraying process; self-fluxing powder alloys; Ni-B-Si coatings; grey cast iron

\section{Introduction}

The methods of thermal spraying of coatings have significantly contributed to the protection of working surfaces of machine elements and devices operating in conditions of abrasive, erosive and corrosive wear $[1 \div 4]$. The production of the coating allows combining the favorable properties of the substrate with the wear resistance, hardness and heat resistance of the coating, and separates the load transfer function from protection against the influence of the work environment of the element. Thermal spraying is an effective and economical process of increasing the durability of new elements, as well as a technique very useful for

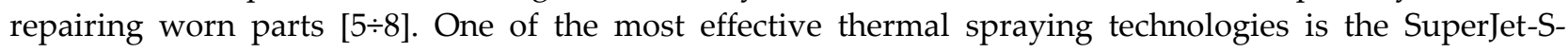
Eutalloy ${ }^{\circledR}$ process (Castolin Eutectic, Gliwice, Poland), which allows very even and precise application of wear protective coatings using a special oxygen-acetylene torch [9]. In the powder flame spraying method, the coated elements are heated to a temperature of $150 \div 500{ }^{\circ} \mathrm{C}$, after which the plasticized and partially melted powder particles are accelerated towards the workpiece, and then they hit the surface of the substrate creating a mechanically bonded pre-layer with a thickness of $0.1 \div 0.2 \mathrm{~mm}$. The precoat protects the surface of the substrate from oxidation. Then the element heats up again to a temperature of $600 \div 700{ }^{\circ} \mathrm{C}$ and puts successive layers of coating [2,9]. It is recommended that the thickness of the layer made in one pass not exceed $2 \mathrm{~mm}$. Each subsequent layer is melted by heating to the temperature within the liquidus-solidus range of the sprayed alloy. The combination of the coating with the native material is most often diffusive in the absence of melting the substrate or metallurgical with slight melting, which further increases the adhesion of the coating. The coating is compact and does not dilute with the components of the native material, which preserves all its properties. This method is used for elements that are required to be highly resistant to abrasion, erosion, corrosion, as well as impact loads and high temperatures $[2,10 \div 13]$. Self-fluxing powders with simultaneous or subsequent remelting are used for spraying with the SuperJet-S-Eutalloy® system. Powders based on $\mathrm{Ni}, \mathrm{Co}$ and $\mathrm{Ni}-\mathrm{Cr}$ alloys are mainly used. In the chemical composition of these powders (e.g. Ni-B-Si, Co-Ni-Cr-B-Si or Ni-Cr-B-Fe-Si) in addition to nickel, which improves the spreadability of the weld metal, there is often boron and silicon, which are effective deoxidizers. During the deoxidation reaction, boron and silicon form very fine particles of $\mathrm{B}_{2} \mathrm{O}_{x}$ and $\mathrm{SiO}_{\mathrm{y}}$ oxides, which settle in the coating in the form of 
$\mathrm{B}_{2} \mathrm{O} \times \mathrm{SiO}$ borosilicate thus increasing its hardness [2,3]. In addition, boron and silicon reduce the melting point of the coating material and have high fluxing properties. Many alloys also contain the addition of chromium, which increases the resistance to abrasive wear, erosion and corrosion.

Nickel-based coatings have gained particular recognition and interest of researchers due to their excellent properties in the field of resistance to mechanical damage and corrosion [12:16]. Ni-B-Si alloys are very popular in this area. These alloys are used in industrial applications that are required to have good metal-to-metal friction resistance, excellent corrosion resistance, and workability. For this reason, these coatings are used when spraying iron and steel molds for the processing of glass and plastics, protecting tungsten carbides on drills, repairing wheel teeth, exhaust manifolds, pump bodies, and restoring rollers, bushings and eccentrics. In addition, this type of coating is used as a buffer layer prior to arc welding of difficult-to-weld cast iron, etc. [2,3,5,9].

Coatings made of self-fluxing alloys based on nickel or cobalt containing an addition of Mo (e.g. Ni-CrMo-Si-B-Cu or Co-Mo-Cr-Si) show higher hardness in the temperature range of $400 \div 500{ }^{\circ} \mathrm{C}$ and higher metalmineral abrasion resistance at room temperature compared to a standard Ni-Cr-B-Si alloy. The modified coating releases hard molybdenum-rich phases. This element has a strong carbide and borogenic effect, thanks to which more unbound chromium remains in the matrix, which increases corrosion resistance in $\mathrm{HCl}$ and $\mathrm{HNO}_{3}$ solutions [2]. Spraying technology with simultaneous remelting of the coating made of these alloys is used to protect boiler heat exchanger pipes against erosion and corrosion $[6,7,11,13]$. Usually, before applying this type of coating, it is recommended to properly prepare the substrate by using the abrasive blasting method.

\section{Own research}

\section{Purpose of the research}

The main purpose of the research was to create and compare tribological and structural properties of two different chemical composition of Ni-B-Si type coatings made on the surface of gray cast iron EN GJL 250 in flame spraying technology using Eutalloy ${ }^{\circledR}$ BronzoChrom 10185 and Eutalloy ${ }^{\circledR}$ NiTec 10224 powders.

In both variants, the process of powder flame spraying was carried out in a wide range of parameters, with the intention of establishing technological guidelines enabling the implementation of coatings that meet the following criteria:

- no welding imperfections,

- thickness in one pass amounting to $1.0 \div 2.0 \mathrm{~mm}$,

- lack of partial melting of the base material,

- diffusive nature of the connection with the ground.

The scope of research included, among others:

- determination of optimal parameters of the powder flame spraying process on the basis of preliminary technological tests,

- coating quality assessment depending on process parameters,

- comparison of the metallographic microstructure of coatings, HAZ and native material,

- determination of atomic and mass concentration of elements present in the coating,

- measurement of the coating's hardness, heat affected zone and native material,

- testing the coatings' resistance to abrasive and erosive wear in relation to reference material in the form of wear-resistant steel.

\section{Equipment and materials used to perform the operation}

The powder flame spraying process was carried out on a production stand equipped with a modern and precise, modular system for manual powder flame spraying - the SuperJet-S-Eutalloy ${ }^{\circledR}$ acetylene-oxygen torch (Fig. 1).

Cuboid samples with the dimensions of $75 \times 25 \times 10 \mathrm{~mm}$, made of gray cast iron EN-GJL-250 were subjected to spraying. The surface of the samples before the spraying process, in accordance with the requirements of ISO 2063-1 (Thermal spraying - Zinc, aluminium and their alloys - Part 1: Design considerations and quality requirements for corrosion protection systems, 2017), was subjected to abrasive blasting in a cabin sandblasting machine, using an abrasive medium in the form of a broken iron shot with G34 granulation (grain size $0.8 \div 1.2 \mathrm{~mm}$ ). This treatment was aimed at cleaning the outer surface of samples from contaminants such as rust, scale or grease. After this treatment step, the cast iron samples were subjected to additional brushing to remove possible residues of shot and subsequent chemical treatment with 
tetrachloroethylene. The final surface roughness of the cast iron substrate after shot blasting was $\mathrm{Ra}=12 \mu \mathrm{m}$, $\mathrm{Rz}=85 \mu \mathrm{m}$.

As an additional material for flame spraying, two types of Ni-B-Si metallic powders from Castolin Eutectic with the trade name Eutalloy ${ }^{\circledR}$ BronzoChrom10185 and Eutalloy ${ }^{\circledR}$ NiTec 10224 were used. Chemical composition of gray cast iron according to PN-EN 1561 (Founding - Grey cast irons, 2012) and spraying powders according to the manufacturer's data are given in tables I-III. The physical properties of the weld metal of the powders used are shown in table IV.

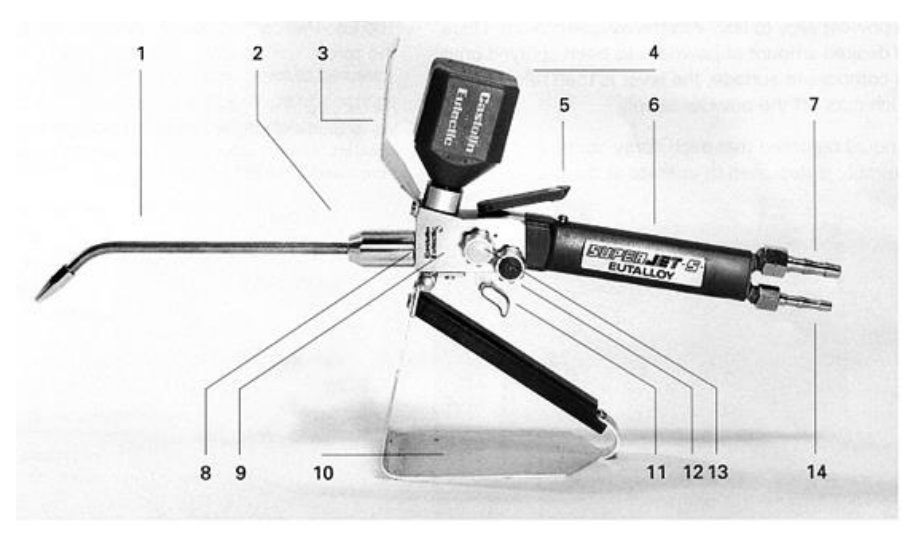

(a)

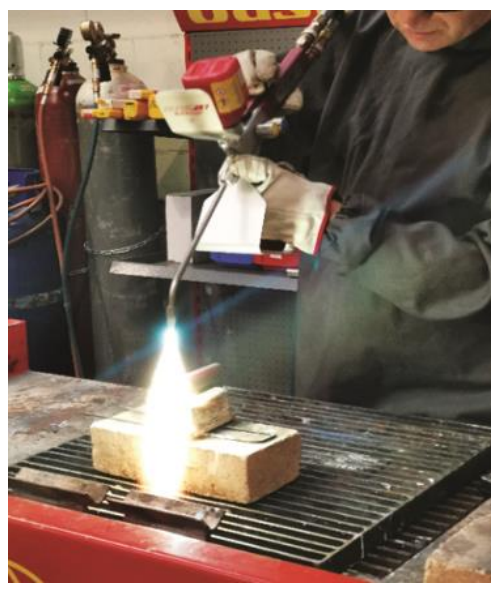

(b)

Fig. 1. Build diagram of Superjet-S-Eutalloy ${ }^{\circledR}$ torch from powder flame spraying: a) 1 - changeable and regulated lance (from A0 to CS5), 2 - securing nut, 3 - upper heat shield, 4 - powder hopper, 5 - powder feed regulation, 6 - handle, 7 - acetylene connector, 8 - injector, 9 - flame arrestor, 10 - lower heat shield, 11 - quick stop valve, 12 - oxygen valve, 13 - acetylene valve, 14 - oxygen connector [9]; b) test plates spraying process

Table I. Chemical composition of EN-GJL-250 grey cast iron according to PN-EN 1561 [18]

\begin{tabular}{ccccc}
\hline \multicolumn{5}{c}{ Chemical composition, wt.\% } \\
\hline $\mathbf{C}$ & $\mathbf{S i}$ & $\mathbf{M n}$ & $\mathbf{S} \max$ & $\mathbf{P} \max$ \\
$3.00 \div 3.25$ & $1.85 \div 2.10$ & $0.40 \div 0.70$ & 0.12 & 0.25 \\
\hline
\end{tabular}

Table II. Chemical composition of deposited metal according to manufacturer data (Castolin Eutectic) of powder Eutalloy ${ }^{\circledR}$ BronzoChrom 10185

\begin{tabular}{cccccc}
\hline \multicolumn{5}{c}{ Chemical composition, wt.\% } \\
\hline $\mathbf{C}$ & $\mathrm{Cr}$ & Fe & B & Si & Ni \\
$\leq 0.1$ & $\leq 0.5$ & $\leq 0.5$ & 2.5 & 3.0 & rest \\
\hline
\end{tabular}

Table III. Chemical composition of deposited metal according to manufacturer data (Castolin Eutectic) of powder Eutalloy ${ }^{\circledR} \mathrm{NiTec} 10224$

\begin{tabular}{cccccc}
\hline \multicolumn{5}{c}{ Chemical composition, wt. $\%$} \\
\hline $\mathbf{C}$ & $\mathbf{C r}$ & $\mathbf{F e}$ & $\mathbf{B}$ & $\mathbf{S i}$ & $\mathbf{N i}$ \\
$\leq 0.1$ & $\leq 0.5$ & $\leq 0.5$ & 1.5 & 2.0 & rest \\
\hline
\end{tabular}

Table IV. Physical properties of EN-GJL-250 grey cast iron according to PN-EN 1561 [18]

\begin{tabular}{cccc}
\hline & \multicolumn{2}{c}{ Mechanical properties } \\
Strength $\mathbf{R}_{\mathbf{m}}, \mathbf{M P a}$ & Hardness, $\mathbf{H B} \mathbf{3 0}$ & Melting point, ${ }^{\circ} \mathbf{C}$ & ${\text { Thermal resistance, }{ }^{\circ} \mathbf{C}}$ \\
\hline $250 \div 350$ & $180 \div 225$ & 1200 & $\leq 600$ \\
\hline
\end{tabular}

Table IV. Physical properties of the weld metal of Eutalloy ${ }^{\circledR}$ BronzoChrom 10185 and Eutalloy ${ }^{\circledR}$ NiTec 10224 powders according to manufacturer data (Castolin Eutectic)

\begin{tabular}{|c|c|c|c|}
\hline \multicolumn{4}{|c|}{ Mechanical properties of the weld metal ${ }^{1)}$} \\
\hline $\begin{array}{l}\text { Hardness, HV } 30 \\
\text { typical (minimum) }\end{array}$ & Density, $\mathrm{g} / \mathrm{cm}^{3}$ & $\begin{array}{c}\text { Melting range } \\
\text { (solidus/liquidus), }{ }^{\circ} \mathrm{C}\end{array}$ & Thermal resistance of the coating, ${ }^{\circ} \mathrm{C}$ \\
\hline \multicolumn{4}{|c|}{ Eutalloy ${ }^{\circledR}$ BronzoChrom 10185} \\
\hline $390(350)$ & 8.91 & $1050 / 1175$ & $\leq 600$ \\
\hline \multicolumn{4}{|c|}{ Eutalloy ${ }^{\circledR}$ NiTec 10224} \\
\hline $240(200)$ & 8.12 & $1050 / 1280$ & $\leq 600$ \\
\hline
\end{tabular}




\section{Parameters and technique of the powder flame spraying process}

Powder flame spraying was carried out using a two-stage technique. First, before spraying the outer coating, the sample was preheated with a gas burner to a temperature of $300{ }^{\circ} \mathrm{C}$ and a $0.1 \mathrm{~mm}$ thick undercoat was made to protect the surface of the substrate from oxidation. The burner was operated in a flat position, with a rapid straight motion parallel to the long side of the sample, moving the burner to a distance of $d=20$ $\mathrm{mm}$. In the next stage, the sample was again heated to $500^{\circ} \mathrm{C}$, after which another layer was laid, which was then remelted. In this situation, the burner was guided along the entire width of the sample, while moving it along the long edge of the sample, covering its entire surface in one pass, until a coating thickness of more than $1.0 \mathrm{~mm}$ was obtained. The spraying process was carried out in such a way that the distance $d$ between the tip of the torch and the sample surface during powder feeding and remelting was from $24 \mathrm{~mm}$ to $30 \mathrm{~mm}$ (Fig. 2). As a result, the temperature measured by a pyrometer thermometer on the non-sprayed outer surface of the sample did not exceed $550^{\circ} \mathrm{C}$. After the spraying process, the samples were cooled slowly in dry sand. After the samples had cooled down, they were no longer subjected to any heat treatment.

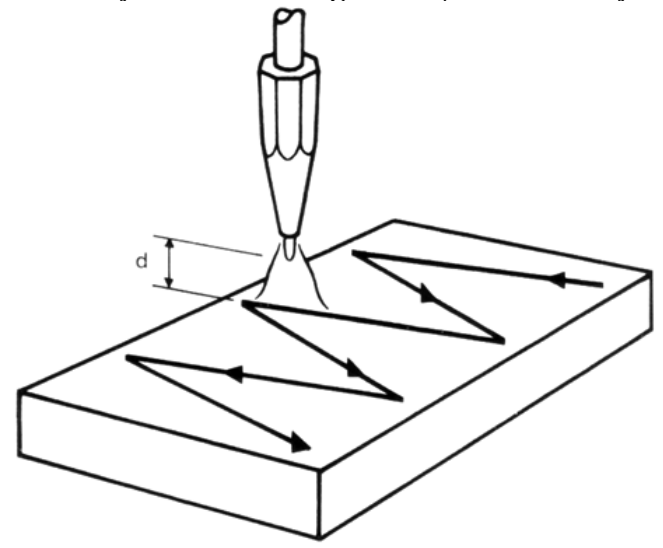

Fig. 2. Diagram of spraying torch trajectory during powder flame spraying [9]

The tests of powder flame spraying of gray cast iron EN-GJL-250 with the use of Ni-B-Si type powders were carried out on the basis of normative requirements for thermally sprayed coatings ISO 14923 (Thermal spraying - Characterization and testing of thermally sprayed coatings, 2005). The criterion of visual assessment of the quality of powder flame sprayed coatings on gray cast iron substrate assumed the implementation of layers characterized by appropriate thickness, good adhesion to the substrate, continuity and uniformity of coverage as well as no cracks and low porosity. Optimal parameters of powder flame spraying of Ni-Si-B coatings, determined on the basis of preliminary technological tests are presented in table $\mathrm{V}$. The view of samples with sprayed coatings is shown in figure 3.

Table V. Powder flame spraying of Eutalloy ${ }^{\circledR}$ BronzoChrom 10185 oraz Eutalloy ${ }^{\circledR}$ NiTec 10224 Ni-B-Si layers on grey cast iron grade EN-GJL-250 parameters

\begin{tabular}{cccccc}
\hline Type of powder & $\begin{array}{c}\text { Oxygen working } \\
\text { pressure, bar }\end{array}$ & $\begin{array}{c}\text { Acetylene } \\
\text { working } \\
\text { pressure, bar }\end{array}$ & $\begin{array}{c}\text { Oxygen } \\
\text { flow rate, } \\
\mathbf{l} / \mathbf{h}\end{array}$ & $\begin{array}{c}\text { Acetylene } \\
\text { flow rate, } \\
\text { //h }\end{array}$ & $\begin{array}{c}\text { Burner's nozzle } \\
\text { working distance, } \\
\text { mm }\end{array}$ \\
\hline Eutalloy ${ }^{\circledR}$ BronzoChrom 10185 & 2.5 & 0.6 & 440 & 400 & $24 \div 30$ \\
Eutalloy $^{\circledR}$ NiTec 10224 & 2.5 & 0.6 & 440 & 400 & $24 \div 30$ \\
\hline
\end{tabular}

Note: A standard modular lance with a working nozzle marked B3 S (injector $\varnothing=0.6 \mathrm{~mm}$ ) was used. spraying was carried out with a normal flame

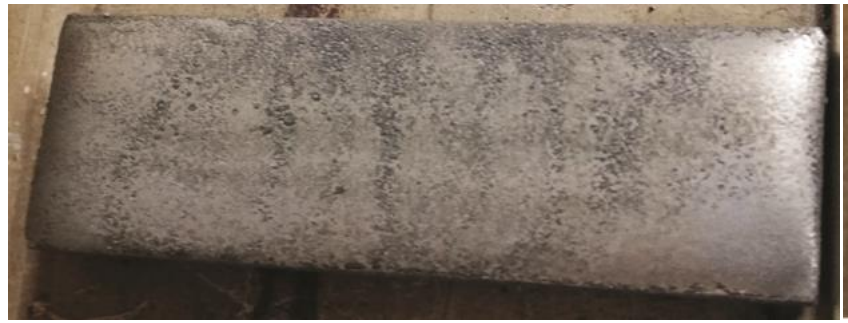

(a)

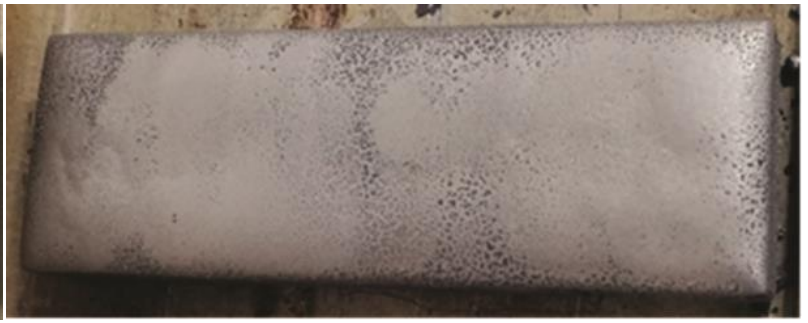

(b)

Fig. 3. View of sample layers after powder flame spraying of a) Eutalloy ${ }^{\circledR}$ BronzoChrom 10185, b) Eutalloy ${ }^{\circledR}$ NiTec 10224 , on grey cast iron grade EN-GJL-250 


\section{Research methodology}

In each case, in order to determine the quality and identify any defects in the form of cracks, discontinuities, unevenness, porosity, irregular shape of the coating or lack of its adhesion to the substrate, the entire surface of the sample was subjected to non-destructive visual (VT) and penetration (PT) tests. The coating properties were assessed on the basis of macro- and microscopic metallographic tests, thickness measurements, HAZ depth, chemical composition tests, $\mathrm{X}$-ray phase analysis, microhardness and resistance to abrasive and erosive wear compared to the reference material.

\section{Non-destructive testing}

Visual tests (external examination) and penetration tests were carried out in accordance with the guidelines contained in applicable standards, i.e. ISO 17637 (Non-destructive testing of welds - Visual testing of fusion-welded joints, 2016) and ISO 3452-2 (Non-destructive testing - Penetrant testing - Part 2: Testing of penetrant materials, 2013) respectively. Visual tests consisted of verification and assessment of the surface condition of the tested coatings with a naked eye (direct visual test). Before starting the actual test, the checked surface was properly prepared by thoroughly cleaning it of all impurities and drying. The color preparation system (System Designation Type II, Sensitivity 2) Cd-2 PT ISO 3452-2 II Cd-2 was used for penetration tests.

\section{Spectrometric analysis and metallographic tests}

First, chemical composition tests were performed on the surface of the compared coatings using the XRF X-MET8000 Expert portable spectrometer (Hitachi High-Technologies Corporation, Tokyo, Japan). In the second stage, microscopic tests were performed on standard metallographic specimens. Samples, prior to observation on a light microscope, were digested in two stages: the native material was revealed using a chemical solution FeCl3Et (Mi19Fe), and the top layers of two Ni-B-Si alloys by electrochemical digestion with a reagent composition: $20 \mathrm{~cm}^{3} \mathrm{HCl}, 10 \mathrm{~g} \mathrm{FeCl}, 30 \mathrm{~cm}^{3}$ distilled water. The etching time was chosen experimentally, individually for each of the materials. Observation and recording of microstructure images was performed using an Olypmus SZX7 stereoscopic microscope (Olympus Corporation, Tokyo, Japan) and an Olypmus GX 71 inverted metallographic microscope (Olympus Corporation, Tokyo, Japan). The obtained macroscopic images allowed the determination of coating's thickness and HAZ depth. Accurate identification (surface and volume) of chemical elements contained in the produced coatings was performed on a ZEISS SUPRA 25 scanning electron microscope (Carl Zeiss AG, Oberkochen, Germany) using the EDS - Energy Dispersive Spectrometry method. X-ray diffraction studies enabling the phase analysis of coatings were performed using an X'Pert Pro PANalytical diffractometer (Malvern Panalytical Ltd, Malvern, United Kingdom). The analysis of the tested layers was performed on the outer surface of the coating in the BraggBrentono system. $X$-ray qualitative phase analysis of the compared coating materials was carried out using a copper lamp $(\lambda=1.54056)$ with a voltage of $40 \mathrm{kV}$ and a current intensity of $30 \mathrm{~mA}$ in the $2 \Theta$ angle range from $30^{\circ}$ to $105^{\circ}$ using a Xcelerator strip detector on the bent beam side.

\section{Abrasive wear resistance tests}

The procedure for testing the metal-mineral abrasive wear resistance of Ni-B-Si coatings and reference material was carried out in accordance with the recommendations of ASTM G65-00, Procedure A (Standard Test Method for Measuring Abrasion Using the Dry Sand/Rubber Wheel Apparatus). The test stand is shown in figure 4.

The wear test was carried out on previously sprayed samples with the dimensions of $75 \times 25 \times 10 \mathrm{~mm}$, three for each type of coating and three samples of reference material. Before testing, the coating was sanded to obtain an even test surface. During the test, the rubber wheel of the test machine made 6000 turns at the friction wheel against the material under test with a force of $130 \mathrm{~N}$. In accordance with the requirements of the ASTM G65-00 standard, Ottawa AFS Testing Sand 50-70 was used as an abrasive, whose flow rate during the test was $335 \mathrm{~g} / \mathrm{min}$. In order to determine the resistance to abrasive wear, the volume loss of mass was determined, calculated on the basis of the average weight loss of the coating after the wear test and the coating's density, calculated according to the dependence (1). A Radwag Wax 60/220 laboratory scale was used for this purpose, weighing the samples before and after the test with an accuracy of $0.0001 \mathrm{~g}$. The hydrostatic method was used to determine the density of coatings and reference material, which measured the mass of the sample in air, followed by liquids with known properties. 
The obtained data regarding the metal-mineral abrasive wear resistance of the coatings were referred to the reference material in the form of samples of Hardox ${ }^{\circledR} 400$ wear-resistant steel sheet with a nominal hardness of $400 \mathrm{HBW}(\sim 423 \mathrm{HV})$.
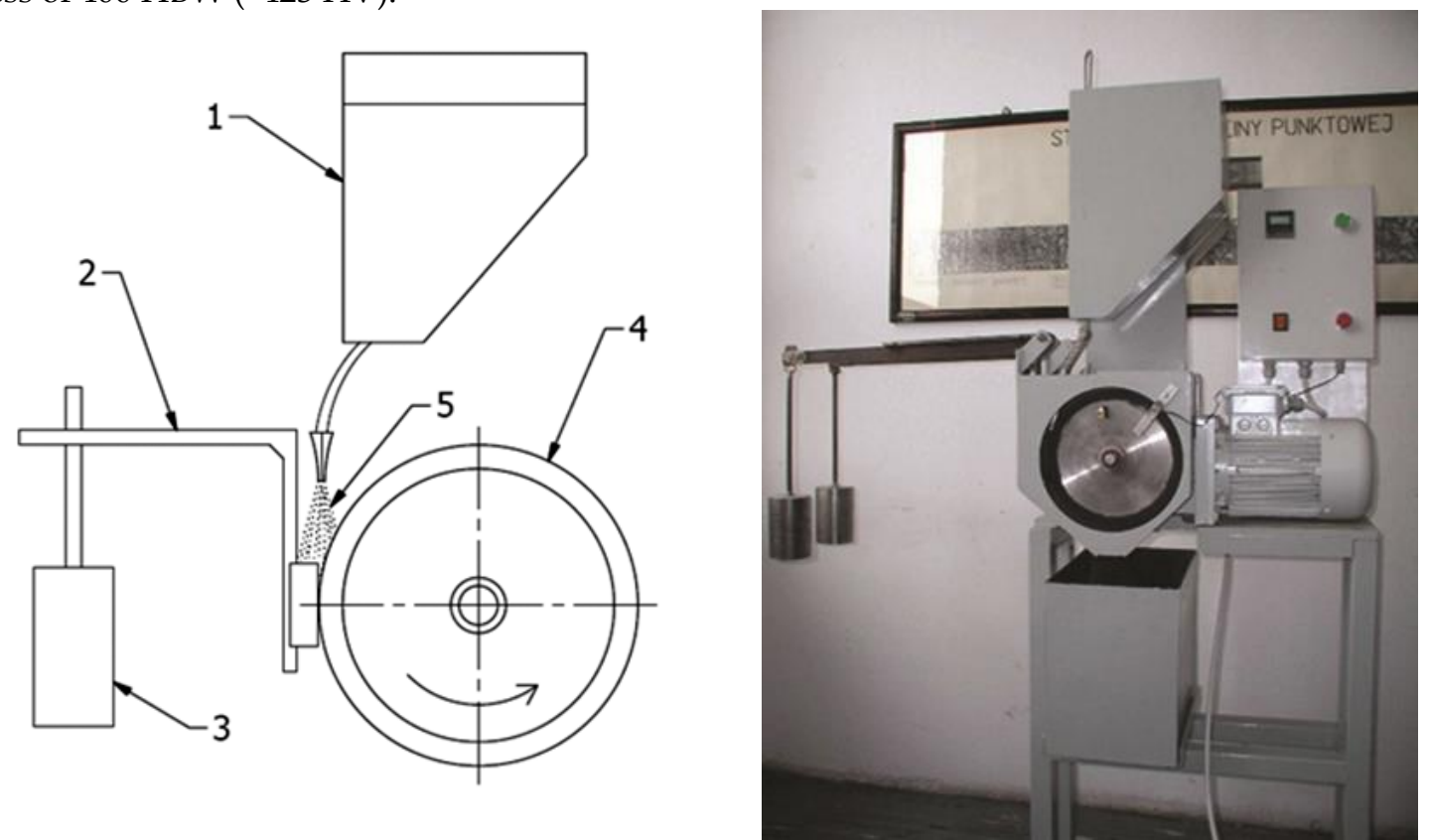

Fig. 4. Abrasive wear test stand according to ASTM G65-00, Procedure A: 1 - abrasive container, 2 - sample holders, 3 - weights, 4 - rubber wheel, 5 - abrasive

\section{Erosion resistance tests}

The erosion resistance test of Ni-B-Si type coatings powder flame sprayed on a cast iron substrate was carried out in accordance with ASTM G76-95 (Standard Test Method for Conducting Erosion Tests by Solid Particle Impingement Using Gas Jets) on the test stand shown in figure $5 . \mathrm{Al}_{2} \mathrm{O}_{3}$ powder with particle diameter up to $71 \mathrm{~mm}$ was used as the erosion material. The velocity of the erodent particles was $70 \pm 2 \mathrm{~m} / \mathrm{s}$, the feeding efficiency of the erodent was set at $2.0 \pm 0.5 \mathrm{~g} / \mathrm{min}$, and the distance between the nozzle outlet and the tested surface of the sample was $10 \mathrm{~mm}$. Erosion resistance tests were carried out at an angle of incidence of $45^{\circ}$.

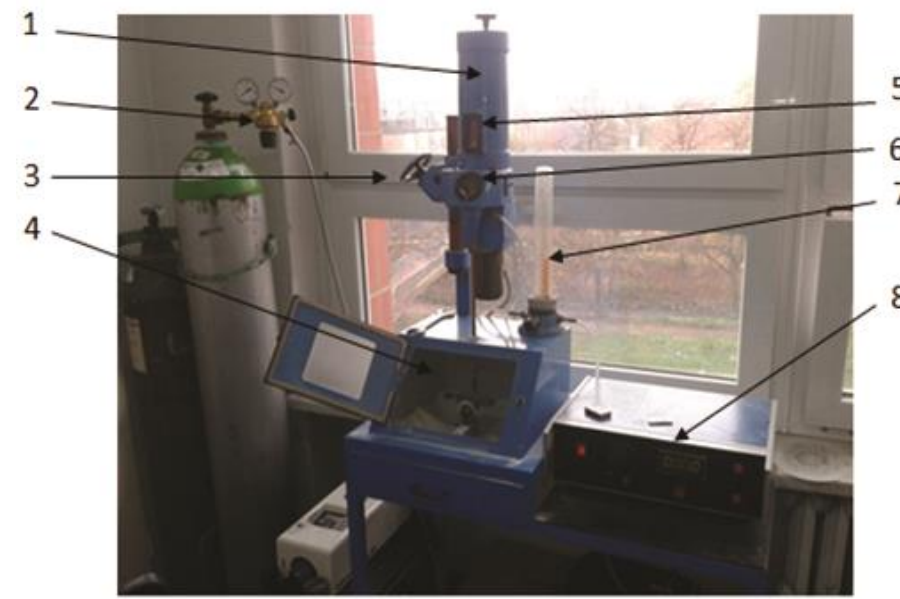

(a)

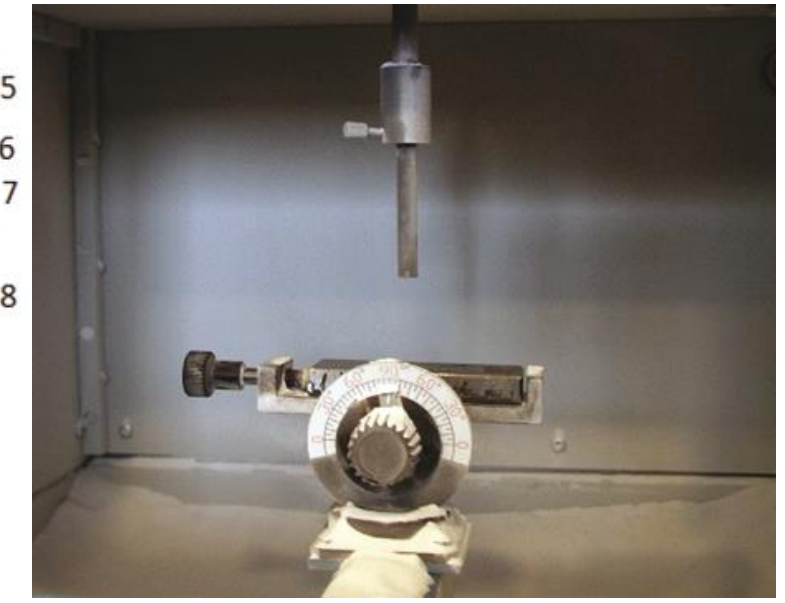

(b)

Fig. 5. Erosion resistance test rig according to ASTM G 76-2: a) general view: 1 - erodent tank, 2 - gas pressure regulator, 3 - distance adjustement of the nozzle from the sample surface, 4 - blasting chamber, 5 - window for checking the erodent level in the tank, 6 - window for checking the erodent feed into the air stream, 7 - flowmeter, 8 - control and adjustment unit, $b$ ) the interior view of the erosion measuring chamber

\section{Hardness measurement}

The hardness of Ni-B-Si coatings was measured using the Rockwell method in accordance with ISO 65081 (Rockwell hardness test - Part 1: Test method, 2016) on a minimally ground outer surface at six measuring 
points with a total loading force of $1471 \mathrm{~N}$ (Fig. 6a) and the Vicker's method based on the ISO 6507-1 standard (Vickers hardness test - Part 1: Test method, 2018) on the polished cross-section of the samples using a $500 \mathrm{G}$ $(4.903 \mathrm{~N})$ load during measurement and maintaining a distance of $0.1 \mathrm{~mm}$ between individual measuring points (Fig. 6b). The hardness measurement on the cross-section was made in the coating, HAZ and native material.

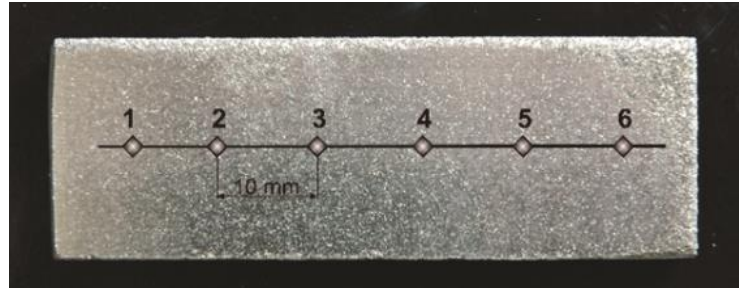

(a)

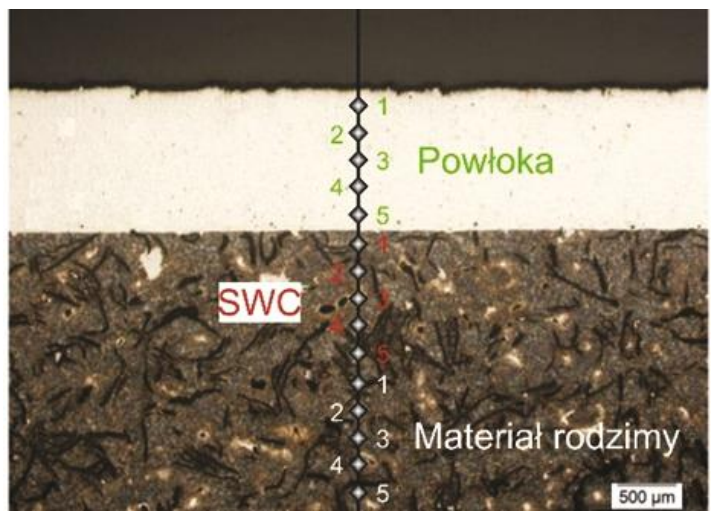

(b)

Fig. 6. Hardness test points location a) on sample outer surface, and b) on cross-section of plated layer and base material

\section{Research results and discussion}

Non-destructive tests results

After visual and penetration tests on the surface of the compared Ni-B-Si coatings made by powder flame spraying, in both analyzed cases, there were no visible indications in the form of welding incompatibilities such as cracks (100), surface pores (2017), excessive convexity (503), wrong edge (505), spatter (602). The coatings made were characterized by a high smoothness of the surface and uniformity of distribution of the weld metal (Fig. 3). In the case of using additional material in the form of Eutalloy ${ }^{\circledR}$ BronzoChrom 10185 powder as well as Eutalloy ${ }^{\circledR}$ NiTec 10224 powder, in the scope of applied technological parameters of powder flame spraying, it is possible to produce coatings that meet the B quality level, which according to ISO 5817 (Welding - Fusion-welded joints in steel, nickel, titanium and their alloys (beam welding excluded) - Quality levels for imperfections, 2014) meets the highest requirements for layers made.

\section{Results of spectrometric analysis and metallographic tests}

The results of spectrometric testing of native material and produced Ni-B-Si coatings are presented in tables VI $\div$ VII. Analysis of the results showed that the chemical composition of gray cast iron EN-GJL-250 and weld metal powders Eutalloy ${ }^{\circledR}$ BronzoChrom 10185 and Eutalloy ${ }^{\circledR}$ NiTec 10224 is in accordance with the declaration of producers of native material and additional materials.

Table VI. Chemical composition of EN-GJL-250 grey cast iron according to according to spectrometric analysis

\begin{tabular}{ccccc}
\hline C & \multicolumn{4}{c}{ Chemical composition ${ }^{1)}$, wt.\% } \\
\hline 3.17 & Si & Mn & S max & P max \\
\hline
\end{tabular}

Note: ${ }^{1)}$ the table gives average values from 5 measurements

Table VII. Chemical composition of the weld metal of Eutalloy ${ }^{\circledR} 10185$ powder according to spectrometric analysis

\begin{tabular}{|c|c|c|c|c|c|}
\hline \multicolumn{6}{|c|}{ Chemical composition $^{1)}$, wt.\% } \\
\hline $\mathrm{C}$ & $\mathrm{Cr}$ & Fe & B & Si & $\mathbf{N i}$ \\
\hline 0.09 & 0.46 & 0.43 & 2.34 & 2.87 & 93.81 \\
\hline
\end{tabular}

Note: ${ }^{1)}$ the table gives average values from 5 measurements

Table VIII. Chemical composition of the weld metal of Eutalloy ${ }^{\circledR}$ NiTec 10224 powder according to spectrometric analysis

\begin{tabular}{cccccc}
\hline & \multicolumn{4}{c}{ Chemical composition', wt.\% } \\
C & Cr & Fe & B & Si & Ni \\
\hline 0.08 & 0.48 & 0.44 & 1.37 & 1.78 & 95.85 \\
\hline
\end{tabular}

Note: ${ }^{1)}$ the table gives average values from 5 measurements 


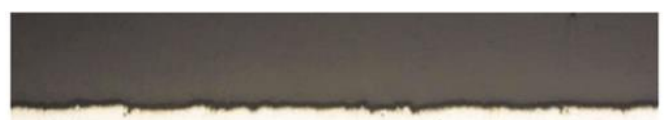

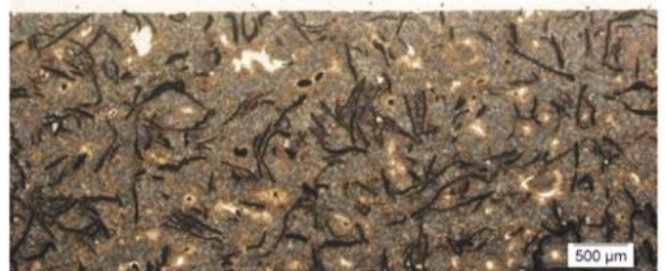

(a)

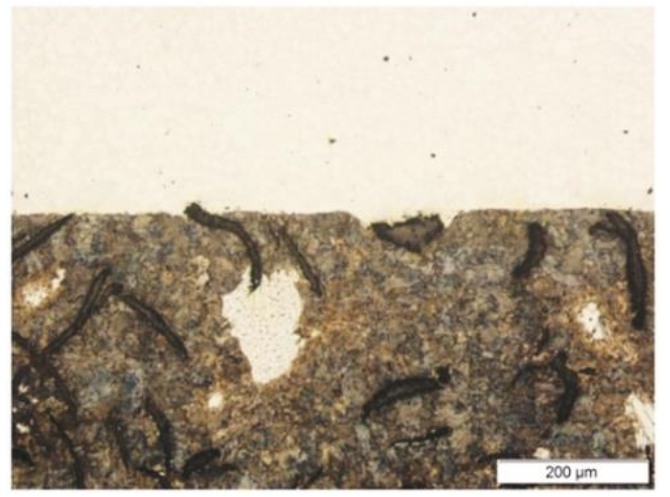

(c)

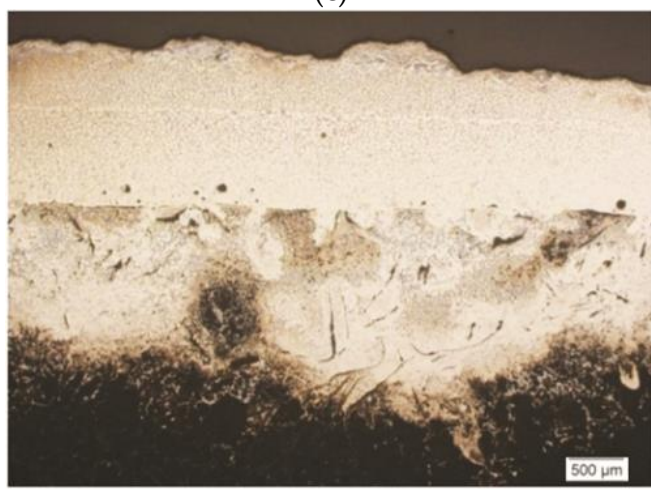

(e)

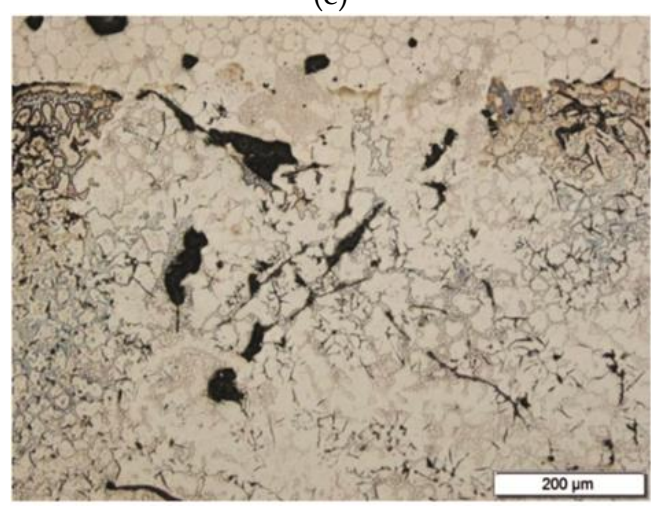

(g)

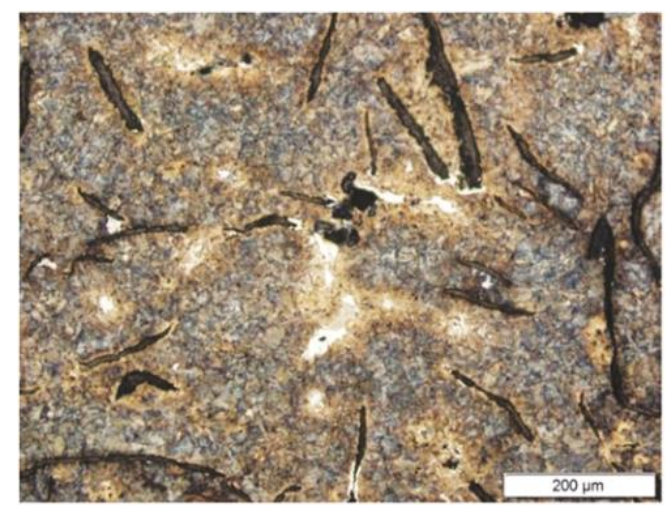

(b)

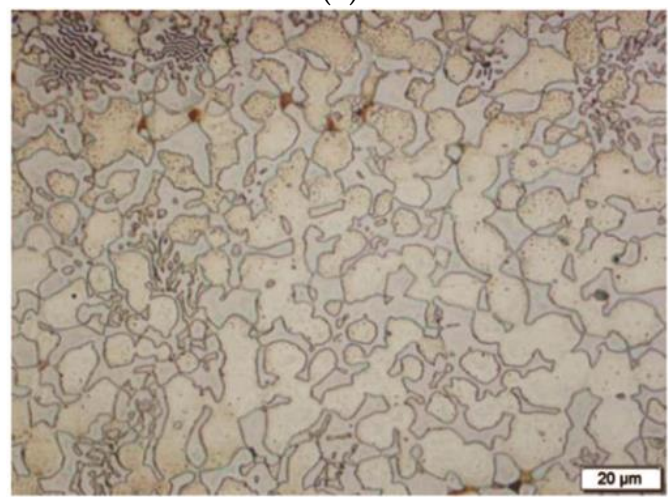

(d)

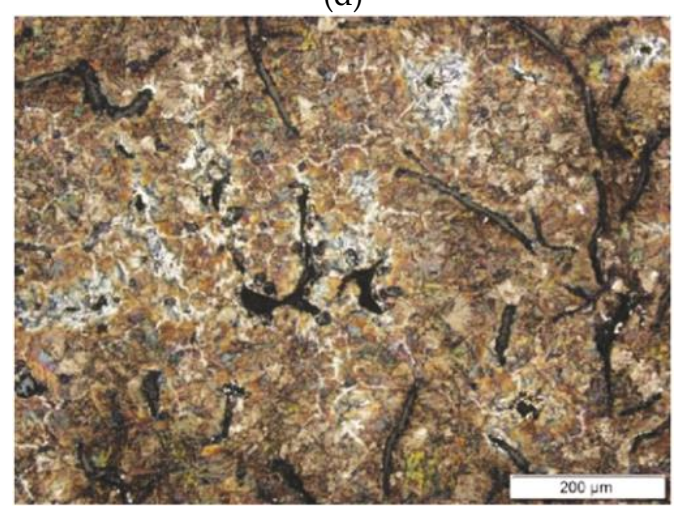

(f)

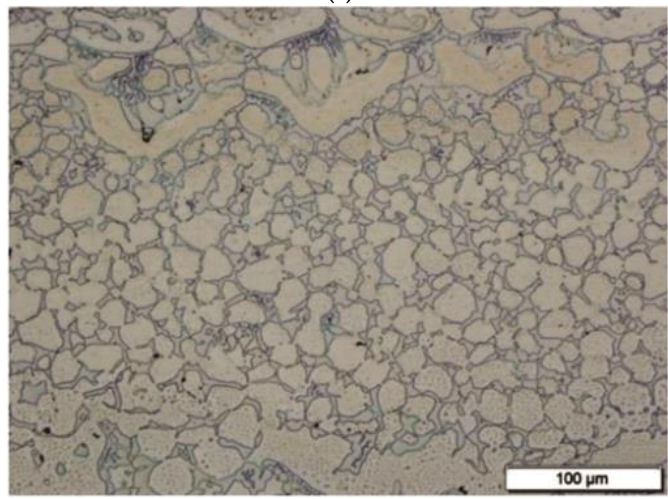

(h)

Fig. 7. Microstructure on Ni-B-Si type layers powder flame sprayed on grey iron grade EN-GJL-250 substrate: a) general view, b) cast iron microstructure, c) HAZ microstructure, d) Eutalloy ${ }^{\circledR}$ BronzoChrom 10185 layer microstructure, general view, f) grey cast iron microstructure, g) HAZ microstructure, h) Eutalloy ${ }^{\circledR}$ NiTec 10224 layer microstructure

Macroscopic tests of Ni-B-Si coatings and native material made of gray cast iron EN GJL 250, both in the case of samples sprayed with Eutalloy ${ }^{\circledR}$ BronzoChrom 10185 powder and Eutalloy ${ }^{\circledR}$ NiTec 10224 powder, did not reveal any welding incompatibilities in the coating as well as in the area transition lines between the coating and the native material, such as: cracks, lack of fusion and excessive penetration, gas voids and other such discontinuities. Only small gas blisters were observed on the cross-section of the coatings. 
The lack of welding incompatibilities indicates that the substrate is properly prepared and protected against oxidation, and that spraying parameters are correctly selected. Samples with a layer sprayed with the Eutalloy ${ }^{\circledR}$ BronzoChrom 10185 powder were diffusive on the entire surface of the connection of the coating with the native material without partial melting of the native material (Fig. 7a). In the case of samples with a coating sprayed with Eutalloy ${ }^{\circledR}$ NiTec 10224 powder, the cast iron substrate slightly melted (Fig. 7e). Both coatings produced had a biphasic partly dendritic structure, which was a solid solution $\gamma-(\mathrm{Ni}, \mathrm{Fe}, \mathrm{Cr})$ and fine-grained eutectic type $\mathrm{Ni}_{3} \mathrm{Si} / \mathrm{Ni} 3 \mathrm{~B}$ (Fig. $7 \mathrm{~d}$ and Fig. $7 \mathrm{~h}$ ). In a rather narrow heat affected zone of samples sprayed with Eutalloy ${ }^{\circledR}$ BronzoChrom 10185 powder, no significant structural changes were found in the native material. The depth of the heat affected zone and the diffusion of alloying elements of the weld metal into the base material did not exceed $100 \mu \mathrm{m}$. However, in the case of samples with Eutalloy ${ }^{\circledR}$ NiTec 10224 powder coating, the heat affected zone was much wider (Fig. 7e) and the diffusion depth of the alloying elements of the coating towards the material exceeded $1 \mathrm{~mm}$. The melting of the base material was caused by a slightly higher melting point of Eutalloy ${ }^{\circledR}$ NiTec 10224 metallic powder than the melting
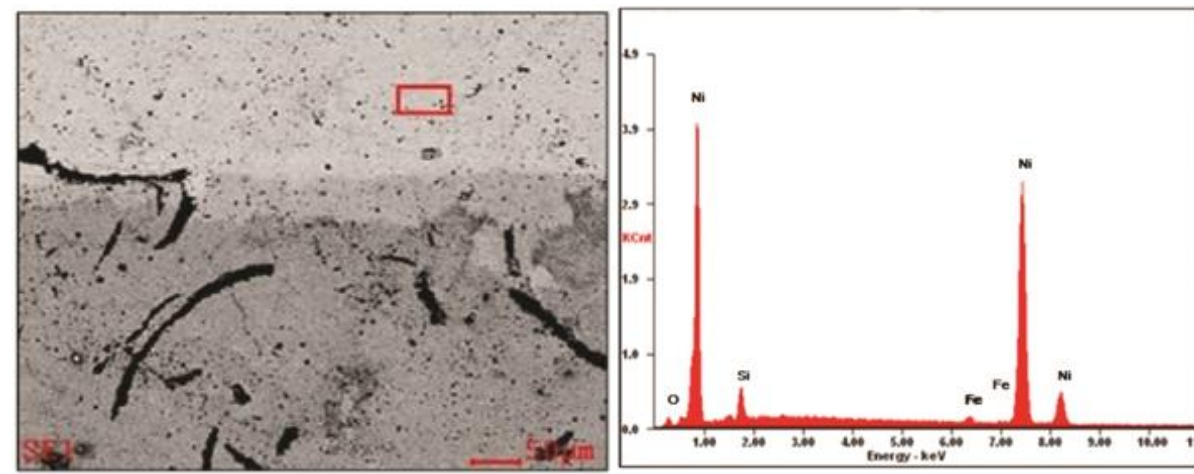

(a)
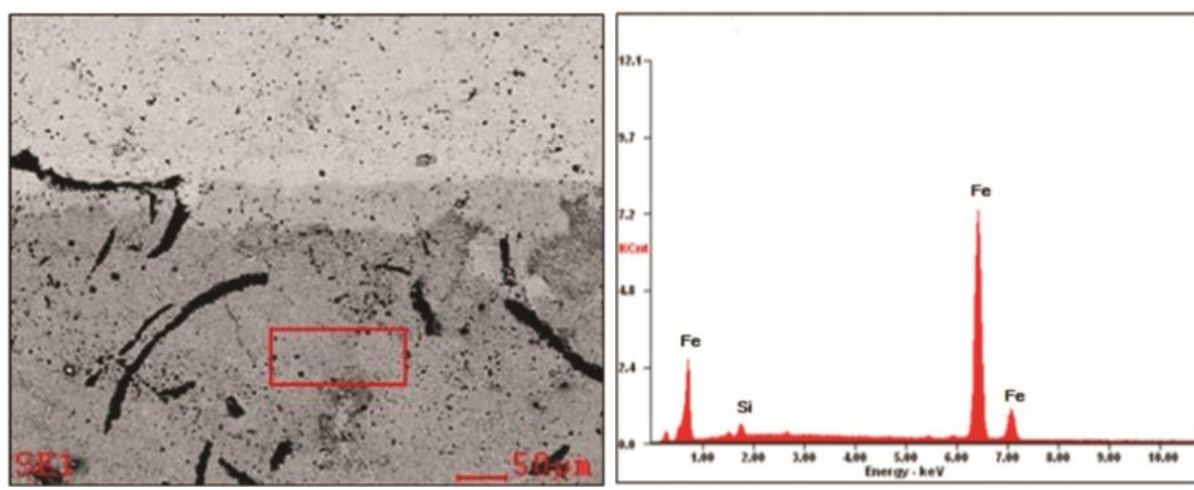

(b)

\begin{tabular}{|c|c|c|}
\hline Element & Wt $\%$ & At $\%$ \\
\hline OK & 01.35 & 04.58 \\
\hline SiK & 04.29 & 08.28 \\
\hline FeK & 01.27 & 01.23 \\
\hline NiK & 93.09 & 85.91 \\
\hline Matrix & Correction & ZAF \\
\hline
\end{tabular}

\begin{tabular}{||c|c|c|}
\hline Element & $\boldsymbol{W t} \%$ & At $\%$ \\
\hline SiK & 02.45 & 04.75 \\
\hline FeK & 97.55 & 95.25 \\
\hline Matrix & Correction & ZAF \\
& & \\
& & \\
\hline
\end{tabular}

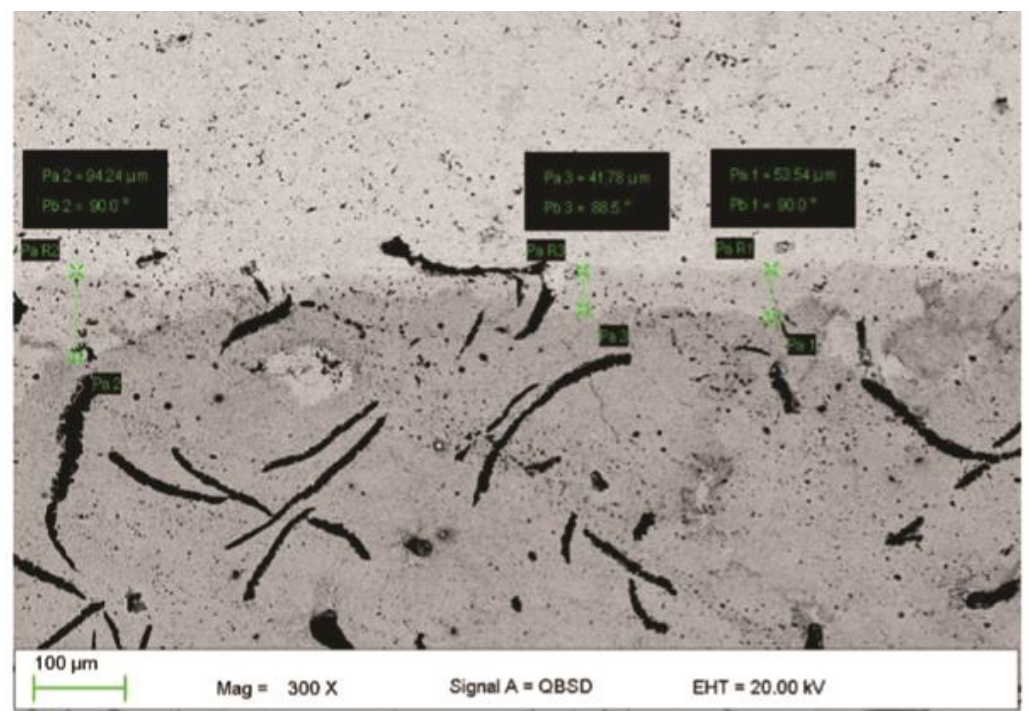

(c)

Fig. 8. Structure and EDS analysis of powder flame sprayed Eutalloy ${ }^{\circledR}$ BronzoChrom 10185 layer (a), substrate grey cast iron grade EN-GJL-250 (b), and diffusion layer measurements (c) 

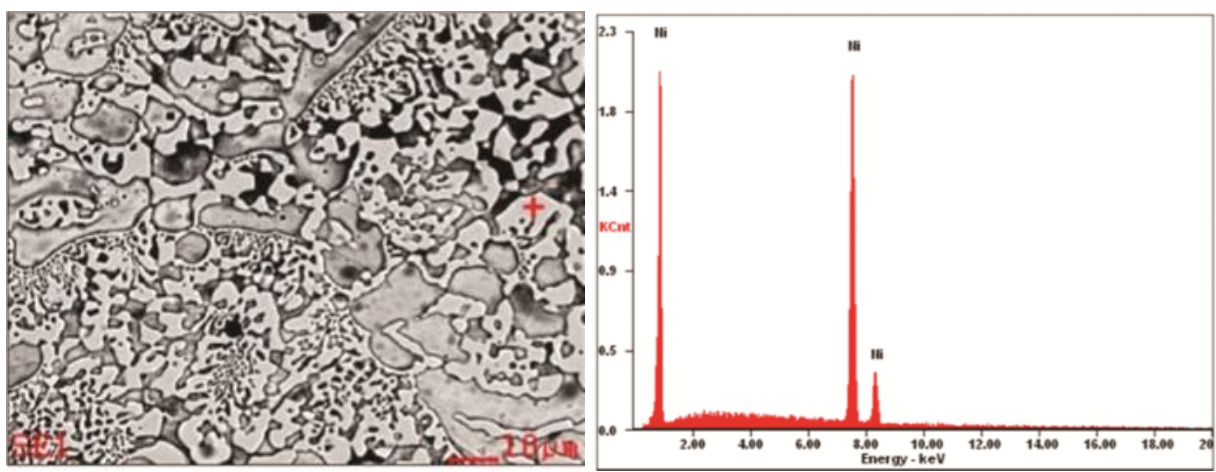

\begin{tabular}{|l|l|l|}
\hline Element & Wt\% & At\% \\
\hline NiK & 100.00 & 100.00 \\
\hline Matrix & Correction & ZAF \\
\hline
\end{tabular}
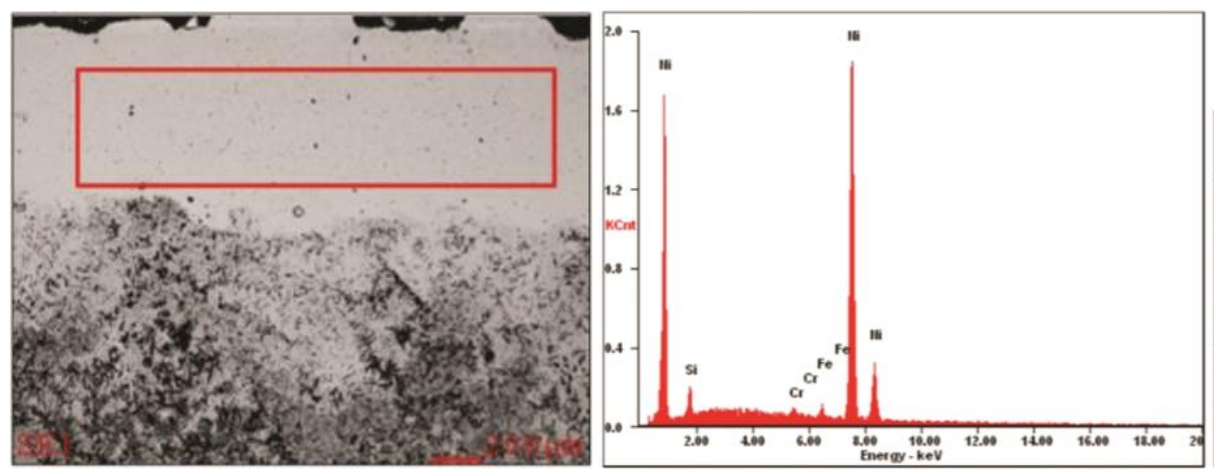

\begin{tabular}{|l|l|l|}
\hline Element & We\% & At\% \\
\hline SiK & 02.59 & 05.26 \\
\hline CrK & 00.91 & 00.99 \\
\hline FeK & 01.68 & 01.72 \\
\hline NiK & 94.82 & 92.03 \\
\hline Matrix & Correction & ZAF \\
\hline
\end{tabular}

(b)
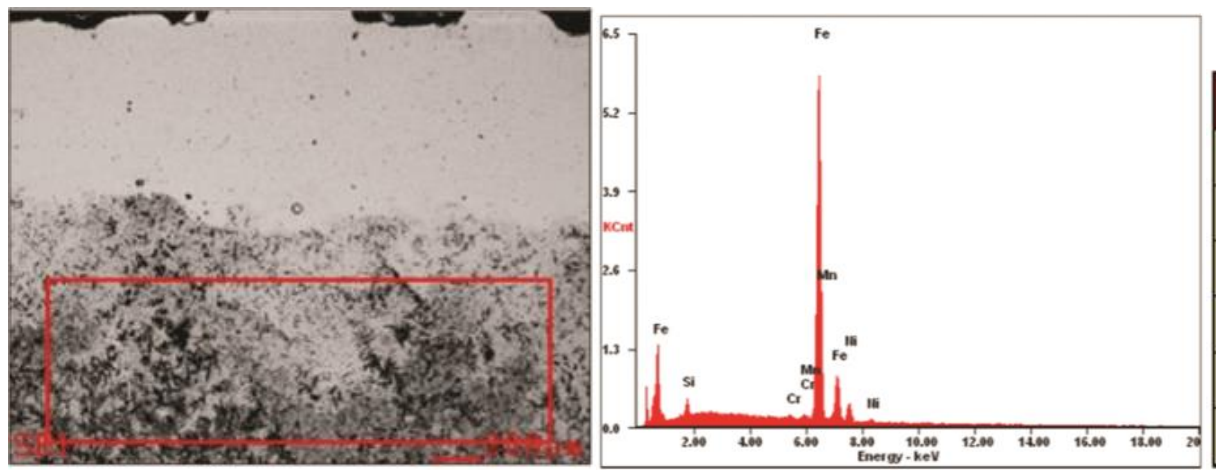

\begin{tabular}{|l|l|l|}
\hline Element & Wt\% & At\% \\
\hline SiK & 02.17 & 04.24 \\
\hline CrK & 00.51 & 00.54 \\
\hline MnK & 01.08 & 01.08 \\
\hline FeK & 88.56 & 86.97 \\
\hline NiK & 07.68 & 07.17 \\
\hline Matrix & Correction & ZAF \\
\hline
\end{tabular}

(c)

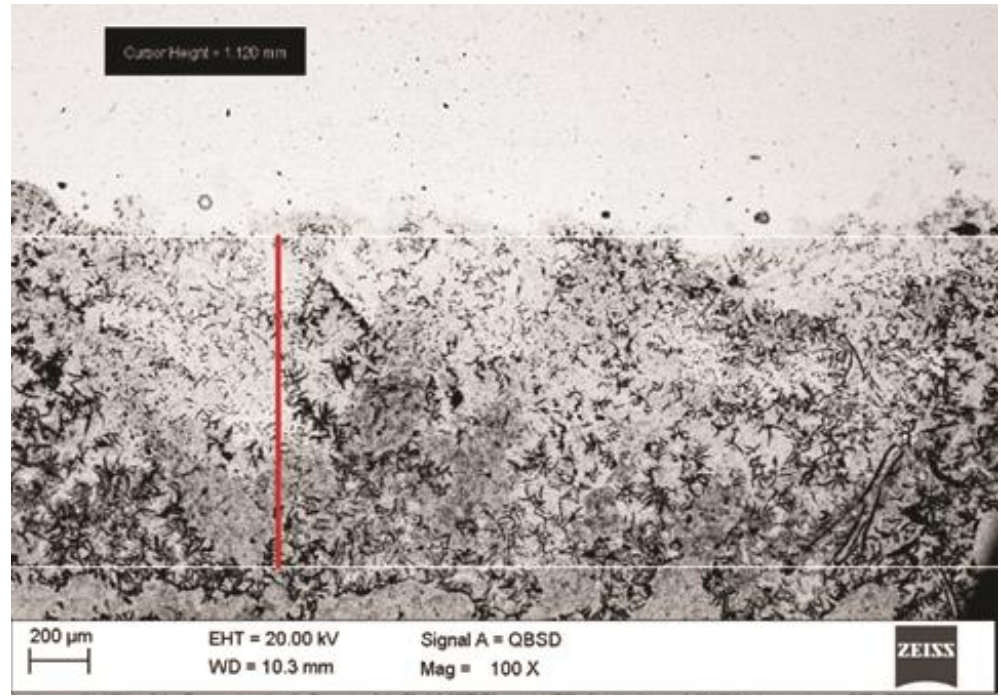

(d)

Fig. 9. Structure and EDS analysis of powder flame sprayed Eutalloy ${ }^{\circledR} \mathrm{NiTec} 10224$ layer (a) and (b), substrate grey cast iron grade EN-GJL-250 (c), and diffusion layer measurements (d)

point of EN-GJL 250 gray cast iron. During the remelting of cast iron with a gas flame, the austenitization temperature of gray cast iron in the HAZ increased in the area of the melted substrate. The increase in the transition temperature of gray cast iron austenite to a temperature of about $911^{\circ} \mathrm{C}$ increased the width of the 
area hardened in HAZ. In figure $7 \mathrm{~g}$, the dissolution of graphite flakes can be observed, which causes carbon to go into solution. The structure of the base material outside of HAZ was typical for cast iron EN-GJL 250 grade. Graphite in the matrix was in the form of flakes with an average size of approx. $100 \mu \mathrm{m}$. Graphite precipitations were distributed evenly over the entire cross-sectional area of the sample. No non-metallic inclusions or impurities in cast iron were also observed. Exemplary macrostructures of the area of connection of Ni-B-Si type coatings with a cast iron substrate are shown in figure 7. The determined thickness of coatings made using flame spraying technology with Ni-B-Si type powders was in the range of $1.0 \div 2.0 \mathrm{~mm}$.

Diffractograms obtained in the phase composition tests of sprayed coatings are presented in figures $8 \div 10$. Tests of the phase composition of flame-sprayed coatings with Eutalloy ${ }^{\circledR}$ BronzoChrom 10185 and Eutalloy ${ }^{\circledR}$ NiTec 10224 powders on gray cast iron substrate EN-GJL 250, mainly revealed a solid nickel solution crystallizing in a surface-centered regular system. The presence of the $\mathrm{Ni}_{3} \mathrm{Si}$ phase was also found, while the expected contribution of the $\mathrm{Ni} 3 \mathrm{~B}$ phase was not clearly confirmed.

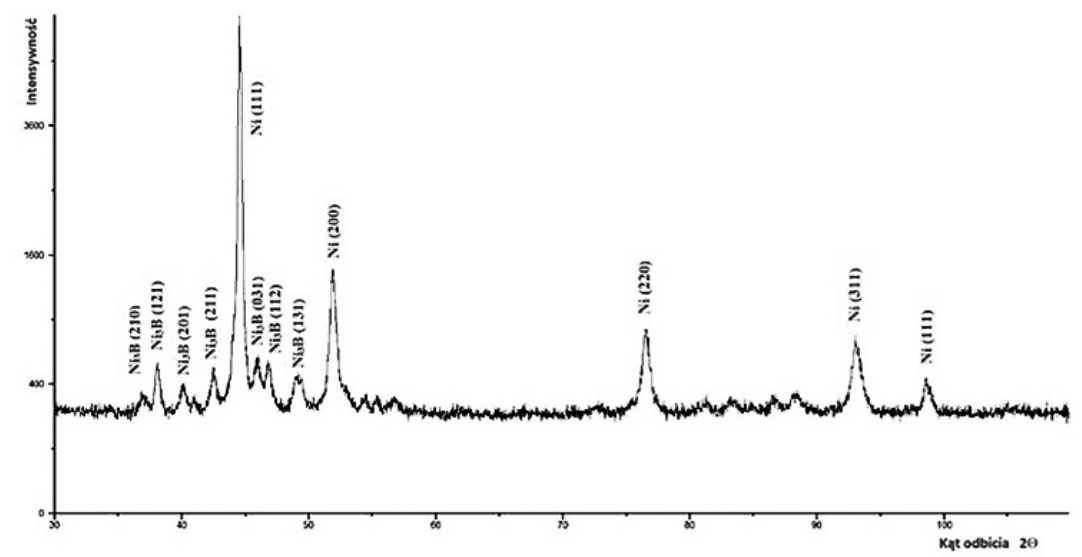

(a)

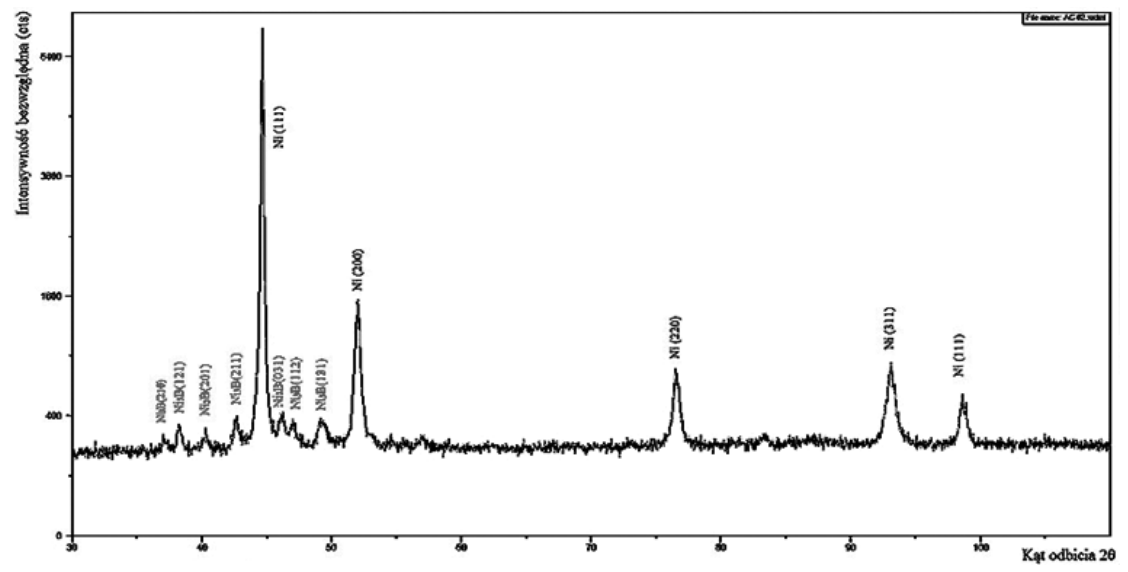

(b)

Fig. 10. XRD pattern of powder Eutalloy ${ }^{\circledR}$ BronzoChrom 10185 (a) and powder Eutalloy ${ }^{\circledR}$ NiTec 10224 (b) flame sprayed coating on grey cast iron EN-GJL 250

\section{Results of abrasion and erosion resistance tests}

Tests of resistance to abrasive wear allowed determining the resistance of Ni-B-Si coatings to wear under metal-mineral abrasion conditions. The assessment of wear consisted in determining the weight loss of the sample during the test (based on weight measurements before and after the test) as well as the volume loss and determining the abrasion resistance relative to the reference sample of wear-resistant steel, taking into account the actual density of the tested materials. The results of the tests and measurements are shown in figure 11 and table IX.

The results of the erosion test in which the abrasive stream hit the samples with coatings set at an angle of $45^{\circ}$ are shown in table X. In this case, also the results of the measurement of wear were given as the loss of mass and volume of the coating in the area of erodent interaction and they were related to the erosive resistance of the sample with wear-resistant steel. The coating produced using Eutalloy ${ }^{\circledR}$ BronzoChrom 10185 powder was characterized by better resistance to abrasive and erosive wear. This condition was probably due to the greater amount of fine and hard inclusions in the form of boron and silicon oxides embedded in the coating's matrix. 


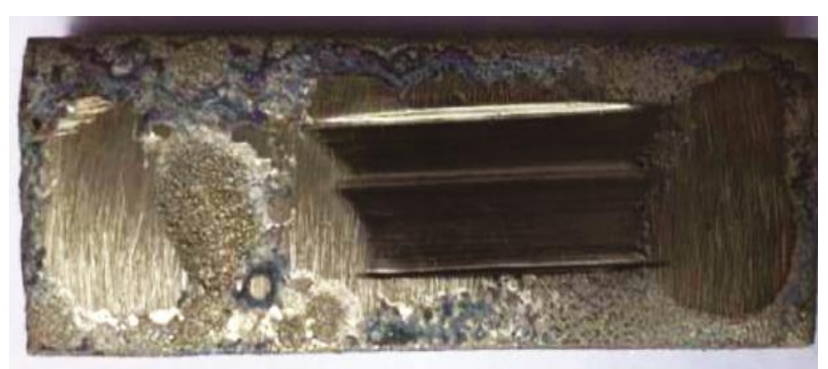

(a)

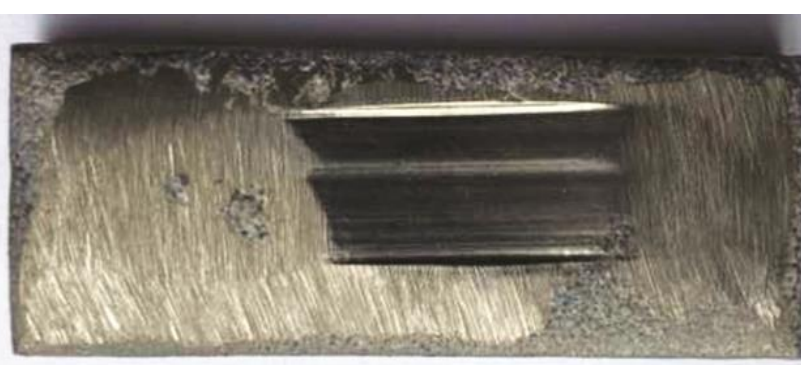

(b)

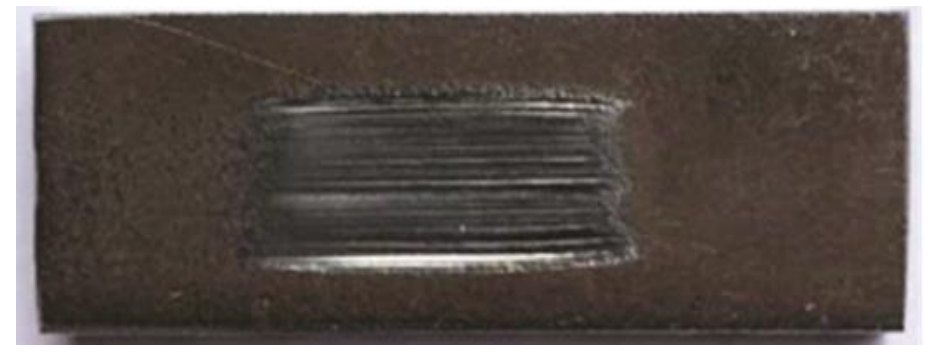

(c)

Fig. 11. Surface view after abrasive wear test according to ASTM G65-00, Procedure A; a) Eutalloy ${ }^{\circledR}$ BronzoChrom 10185 layer, b) Eutalloy ${ }^{\circledR}$ NiTec 10224 layer, c) abrasion resistant steel

Table IX. Abrasive wear test results of powder flame sprayed Eutalloy ${ }^{\circledR}$ BronzoChrom 10185 and Eutalloy ${ }^{\circledR}$ NiTec 10224 layers on grey cast iron grade EN-GJL-250 substrate in comparison to abrasion-resistant steel

\begin{tabular}{|c|c|c|c|c|c|c|c|c|}
\hline \multirow[b]{2}{*}{$\begin{array}{l}\text { Type of the } \\
\text { coating's } \\
\text { material }\end{array}$} & \multirow[b]{2}{*}{$\begin{array}{c}\text { Designation } \\
\text { of the } \\
\text { sample }\end{array}$} & \multicolumn{2}{|c|}{ Sample mass, $\mathrm{g}$} & \multirow[b]{2}{*}{$\begin{array}{l}\text { Mass loss, } \\
\mathrm{g}\end{array}$} & \multirow[b]{2}{*}{$\begin{array}{c}\text { Coating } \\
\text { density } \\
\text { g/cm } \\
\mathrm{cm}^{3}\end{array}$} & \multirow[b]{2}{*}{$\begin{array}{l}\text { Volume loss, } \\
\text { mm }^{3}\end{array}$} & \multirow[b]{2}{*}{$\begin{array}{c}\text { Average } \\
\text { volume loss, } \\
\mathrm{mm}^{3}\end{array}$} & \multirow[b]{2}{*}{$\begin{array}{l}\text { Abrasion } \\
\text { resistance in } \\
\text { regard to the } \\
\text { reference } \\
\text { sample }\end{array}$} \\
\hline & & $\begin{array}{c}\text { before } \\
\text { the test, } \\
\mathrm{g}\end{array}$ & $\begin{array}{c}\text { after the } \\
\text { test, } \\
\mathrm{g}\end{array}$ & & & & & \\
\hline \multirow{2}{*}{ Eutalloy ${ }^{\circledR} 10185$} & $\mathrm{BC} 1$ & 149.5558 & 148.2918 & 1.9117 & 8.8265 & 216.5874 & \multirow{2}{*}{215.2966} & \multirow{2}{*}{0.81} \\
\hline & $\mathrm{BC} 2$ & 146.2647 & 144.3621 & 1.9026 & 8.8904 & 214.0058 & & \\
\hline Eutalloy $^{\circledR}$ & NT1 & 144.3192 & 142.2164 & 2.1028 & 8.1066 & 260.0843 & \multirow{2}{*}{259.3935} & \multirow{2}{*}{0.68} \\
\hline 10224 & NT2 & 148.6456 & 146.5484 & 2.0972 & 8.0125 & 258.7027 & & \\
\hline Reference & $\mathrm{H} 1$ & 116.0725 & 114.7311 & 1.3414 & 7.7146 & 173.8781 & \multirow{2}{*}{175.1271} & \multirow{2}{*}{1.00} \\
\hline sample & $\mathrm{H} 2$ & 120.6811 & 119.3211 & 1.3600 & 7.7108 & 176.3760 & & \\
\hline
\end{tabular}

Note: ${ }^{1)}$ the coating density of each sample is the average of three measurements

Table X. Erosion resistance wear test results of powder flame sprayed Eutalloy ${ }^{\circledR}$ BronzoChrom 10185 and Eutalloy ${ }^{\circledR}$ NiTec 10224 layers on grey cast iron grade EN-GJL-250 substrate in comparison to abrasion-resistant steel

\begin{tabular}{|c|c|c|c|c|c|c|c|c|}
\hline $\begin{array}{l}\text { Type of the } \\
\text { coating's } \\
\text { material }\end{array}$ & $\begin{array}{c}\text { Angle of } \\
\text { incidence } \\
\text { of the } \\
\text { erodent, }\end{array}$ & $\begin{array}{c}\text { No, of } \\
\text { the } \\
\text { sample }\end{array}$ & $\begin{array}{c}\text { Mass } \\
\text { loss, } \\
\text { mg }\end{array}$ & $\begin{array}{l}\text { Volume loss, } \\
\text { mm }^{3}\end{array}$ & $\begin{array}{l}\text { The speed } \\
\text { of erosion, } \\
\mathrm{mg} / \mathrm{min}\end{array}$ & $\begin{array}{c}\text { Resistance to } \\
\text { erosive wear, } \\
0,001 \mathrm{~mm}^{3} / \mathrm{g}\end{array}$ & $\begin{array}{c}\text { Average resistance } \\
\text { to erosive wear, } \\
0,001 \mathrm{~mm}^{3} / \mathrm{g}\end{array}$ & $\begin{array}{l}\text { Relative } \\
\text { erosion } \\
\text { resistance }{ }^{1)}\end{array}$ \\
\hline Eutalloy $^{\circledR}$ & \multirow{6}{*}{$45^{\circ}$} & BC1 & 3.5 & 0.3965 & 0.35 & 19.58 & \multirow{2}{*}{18.96} & \multirow{2}{*}{1.20} \\
\hline 10185 & & BC2 & 3.3 & 0.3712 & 0.33 & 18.33 & & \\
\hline Eutalloy $^{\circledR}$ & & NT1 & 4.4 & 0.5428 & 0.44 & 26.8 & \multirow{2}{*}{26.65} & \multirow{2}{*}{0.91} \\
\hline 10224 & & NT2 & 4.3 & 0.5367 & 0.43 & 26.5 & & \\
\hline Reference & & H1 & 3.8 & 0.4926 & 0.38 & 24.37 & \multirow{2}{*}{24.36} & \multirow{2}{*}{1.00} \\
\hline sample & & $\mathrm{H} 2$ & 3.8 & 0.4928 & 0.38 & 24.34 & & \\
\hline
\end{tabular}

Note: ${ }^{1)}$ - the result was referred to samples made of Hardox ${ }^{\circledR} 400$ wear-resistant steel plate with a nominal hardness of 400 HBW. Erosion rate, $\mathrm{g} / \mathrm{min}=$ mass loss of the sample, $\mathrm{mg}$ : exposure time, min; Resistance to erosive wear, $0.001 \mathrm{~mm}^{3} / \mathrm{g}=\mathrm{sample}^{\circ}$ volume loss, $\mathrm{mm}^{3}$ : total mass of erodent used in the test, g. Erosion test parameters: speed $-70 \pm 2 \mathrm{~m} / \mathrm{s}$, temperature $20^{\circ} \mathrm{C}$, erodent $-\mathrm{Al}_{2} \mathrm{O}_{3}$, nominal particle size of the erodent $-50 \mu \mathrm{m}$, amount of erodent administered $-2.0 \pm 0.5 \mathrm{~g} / \mathrm{min}$, test time -10 min, distance between the nozzle and sample $-10 \mathrm{~mm}$, density of coatings and reference material according to table $X$, mass of erodent used in the test $-20.25 \mathrm{~g}$.

\section{Hardness measurement results}

The visible depth of HAZ measured during macroscopic tests for individual coatings produced by powder flame spraying was confirmed by microhardness measurements. The average HRC hardness 
measurement result determined on the outer surface of Ni-B-Si coatings and HV0.5 microhardness tested on the cross-section of the samples is given in Table XI and Table XII. The results are the average of five measurements made in the coating, HAZ and native material. The hardness measurement showed that both for the coating made with Eutalloy ${ }^{\circledR}$ BronzoChrom 10185 powder and Eutalloy ${ }^{\circledR}$ NiTec 10224 powder, the hardness declared by the powder manufacturer was obtained, respectively $39 \mathrm{HRC}(\sim 382 \mathrm{HV})$ and $21 \mathrm{HRC}$ $(\sim 243 \mathrm{HV})$. In the heat affected zone of samples with a coating sprayed with Eutalloy ${ }^{\circledR}$ NiTec 10224 powder, the type of microstructure changed significantly as it moved away from the fusion line. At the fusion line the microstructure of white cast iron was found, and at a further distance the mottled cast iron (Fig. 9d). This condition was caused by a greater amount of heat supplied to the native material during the spraying process, which contributed to an increase in hardness in this area in the range of $461 \div 539 \mathrm{HV} 0.5$. In the heat affected zone of samples with a coating sprayed with Eutalloy® BronzoChrom 10185 powder, the hardness readings were in the range of $297 \div 393$ HV0.5. Analysis of hardness in the native material for both coating materials gave acceptable results at the level of $234 \div 236$ HV0.5, which is consistent with the material characteristics of gray cast iron EN-GJL-250.

Table XI. Hardness test results on surface of powder flame sprayed Eutalloy ${ }^{\circledR}$ BronzoChrom 10185 and Eutalloy ${ }^{\circledR}$ NiTec 10224 layers on grey cast iron grade EN-GJL-250 substrate

\begin{tabular}{ccc}
\hline Type of the coating's material & Measurement point & Hardness on the outer surface of the coating, HRC ( HV) \\
\hline & 1 & 42 \\
& 2 & 36 \\
Eutalloy $^{\circledR} 10185$ & 3 & 38 \\
& 4 & 41 \\
5 & Average & 37 \\
\hline & 2 & 21 \\
Eutalloy $^{\circledR} 10224$ & 3 & 20 \\
& 4 & 21 \\
& 5 & 23 \\
& Average & 20 \\
\hline
\end{tabular}

Table XII. Hardness test results on cross-section of powder flame sprayed Eutalloy® BronzoChrom 10185 and Eutalloy® NiTec 10224 layers on grey cast iron grade EN-GJL-250 substrate

\begin{tabular}{ccccc}
\hline \multirow{2}{*}{$\begin{array}{c}\text { Type of the } \\
\text { coating's material }\end{array}$} & $\begin{array}{c}\text { Measurement } \\
\text { point }\end{array}$ & Coating & Heat affected zone & Native material \\
\hline & 1 & 402 & 393 & 244 \\
& 2 & 397 & 376 & 240 \\
Eutalloy ${ }^{\circledR} 10185$ & 3 & 388 & 357 & 237 \\
& 4 & 363 & 312 & 234 \\
& 5 & 357 & 297 & 225 \\
& Average & 381 & 347 & 236 \\
\hline & 1 & 255 & 539 & 232 \\
Eutalloy ${ }^{\circledR} 10224$ & 2 & 244 & 512 & 227 \\
& 3 & 238 & 495 & 234 \\
& 4 & 251 & 487 & 248 \\
\hline
\end{tabular}




\section{Summary}

By spraying gray cast iron EN GJL 250 with Ni-B-Si type powders, it is possible to produce high-quality coatings with a thickness in the range of $1.0 \div 2.0 \mathrm{~mm}$ in one pass. The coating which was flame sprayed with a powder of the Eutalloy ${ }^{\circledR}$ BronzoChrom 10185 grade was characterized by diffusion bonding and no structural changes in the cast iron substrate. The melting point of Eutalloy ${ }^{\circledR}$ NiTec 10224 powder similar to that of cast iron, determined by the lower content of boron and silicon, resulted in a slight melting of the substrate as well as significant structural changes and an increase in the HAZ hardness of the native material up to 539 HV0.5. The compared coatings were only slightly different in morphology and microstructure. In both cases, the coatings had at least a two-phase structure. X-ray phase analysis, analysis of phase equilibrium plots, review of literature data, hardness measurements and EDS analysis results allowed to identify as nickel silicas $\mathrm{Ni}_{3} \mathrm{Si}$ in the light gray area and solid solution based on $\mathrm{Ni}(\gamma-\mathrm{Ni}, \mathrm{Fe}, \mathrm{Cr})$ in the light area. In the light of the conducted tests, it was not possible to uniquely identify the expected presence in the coatings of the $\mathrm{Ni}_{2} \mathrm{~B}$ phase (nickel borides). The results of the hardness measurement on the outer surface of the coatings were consistent with the powder manufacturer's data. The amount of the coating's wear depended on the chemical composition of the powder used. The coating which was flame sprayed with a Eutalloy ${ }^{\circledR}$ BronzoChrom 10185 powder containing a higher concentration of boron and silicon showed about $13 \%$ lower wear intensity under the influence of mineral abrasive and about $30 \%$ greater resistance to erosive wear than the coating flame sprayed with a Eutalloy ${ }^{\circledR}$ NiTec 10224 powder. This probably was caused by a larger number of small and hard phases embedded in the matrix in the form of borosilicates.

Author Contributions: conceptualization A.C., B.W.; methodology M.A., E.B.; investigation M.A., A.C.; writing - original draft preparation A.C., B.W.; writing - review and editing M.A., E.B.; supervision E.B.; Funding: This research received no external funding.

Acknowledgments: The authors would like to thank the Castolin Eutectic for technical and material support. Conflicts of Interest: The authors declare no conflict of interest.

\section{References}

[1] Tobota K., Chmielewski T., Chmielewski M., Microstructure and selected properties of Ni-Cr-Re coatings deposited by means of HVOF thermal spraying. Welding Technology Review, 2019, Vol. 91(1), 25-30. https://doi.org/10.26628/wtr.v91i1.1000

[2] Bhushan B., Principles and Applications of Tribology, 2013, New York, John Wiley \& Sons, 980.

[3] Marcos Sá DeSousa J., Ratusznei F., Pereira R., de Medeiros Castro R., Mercado Curib E.I., Abrasion resistance of $\mathrm{Ni}-\mathrm{Cr}-\mathrm{B}-\mathrm{Si}$ coating deposited by laser cladding process. Tribology International, 2020, Vol. 143, 106002. https://doi.org/10.1016/j.triboint.2019.106002.

[4] Shveikin G.P., Sokolova N.V., Rudenskaya N.A., Kuzmin V.I., Supersonic plasma and wear-resistant nickel alloy coatings. Доклады Академии Наук, 2015, Vol. 463(3), 309-312.

[5] Ilushchenko A. F., Manoylo E. D., Andreev M. A., Onashchenko F. E., Flame spraying of coatings of self-fluxing alloys. Welding International, 2017, Vol. 31(11), 887-891. https://doi.org/10.1080/09507116.2017.1349279

[6] Hejwowski T., Erosive and abrasive wear resistance of overlay coatings. Vacuum, 2008, Vol. 83(1), 166-170. DOI: 10.1016/j.vacuum.2008.03.029

[7] Majewski D., Hejwowski T., Łukasik D., The influence of microstructure of arc sprayed coatings on wear resistance. Advances in Science and Technology. Research Journal, 2018, Vol. 12(1), 285-292. https://doi.org/10.12913/22998624/86210

[8] Jiméneza H., Olayaa J.J., Alfonsob J.E., Pineda-Vargas C.A., Corrosion resistance of Ni-based coatings deposited by spray and fuse technique varying oxygen flow. Surface and Coatings Technology, 2017, Vol. 321, 341-349. https://doi.org/10.1016/j.surfcoat.2017.04.068.

[9] http://www.castolin.com

[10] Bęczkowski R., Gucwa M., Qualifying of hardfacing surfacing layers operating under conditions of the cement industry. Welding Technology Review, 2015, Vol. 87(9), 43-46. https://doi.org/10.26628/wtr.v87i9.450

[11] Dorfman M.R., Thermal Spray Coatings. Handbook of Environmental Degradation of Materials (Third Edition), 2018, 469488.

[12] Kondej A., Babul T., Microstructure of the Ni-Cr-B-Si coating obtained in surfacing process. Welding Technology Review, 2016, No. 3, 23-26. 
[13] Stack M.M., Chacon-Nava J., Jordan M.P., Elevated temperature erosion of range of composite layers of Ni-Cr based functionally graded material. Materials Science and Technology, 1996, Vol. 12.

[14] Lim L.C., Ming Q., Chen Z.D., Microstructure of laser-clad nikel-based hardfacing alloys. Surface and Coatings Technology, 1996, Vol. 106.

[15] Kochmańska A., Garbiak M., High-Temperature Diffusion Barrier for Ni-Cr Cast Steel. Defect and Diffusion Forum, 2011, Vols. 312-315, 595-60. https://doi.org/10.4028/www.scientific.net/DDF.312-315.595

[16] Li J., Lu L., Lai M.O., Quantitative analysis of the irregularity of graphite nodules in cast iron. Materials Characterization, 2000, Vol. 45, 83-88. DOI: 10.1016/S1044-5803(00)00052-8

(C) 2020 by the authors. Submitted for possible open access publication under the terms and conditions of the Creative Commons Attribution (CC BY) license (http://creativecommons.org/licenses/by/4.0/). 